УДК 821.521

DOI dx.doi.org/10.24866/1997-2857/2020-4/15-24

\title{
РАССКАЗЫ ИЗ «СОБРАНИЯ СТАРОДАВНИХ ПОВЕСТЕЙ» О БУДДИЗМЕ В КИТАЕ
}

\author{
Вступительное слово, перевод и комментарии М.В. Бабковой
}

\begin{abstract}
Публикация представляет перевод избранных историй из 6-го и 7-го свитков «Собрания стародавних повестей», крупнейшего сборника японских коротких поучительных рассказов сэиува. Оба они посвящены истории буддизма в Китае. Но если в 6-м свитке разворачивается повествование о проникновении Закона Будды в Китай и его распространении, то в 7-м свитке развивается одна из тем 6-го - почитание священных текстов. Рассказы для перевода отобраны с целью дать общее представление о характере повествования, круге тем и сюжетов в 6-м и 7-м свитках «Собрания стародавних повестей». Ключевые слова: японская литература, Кондзяку моногатари, сэиува, буддизм, Китай
\end{abstract}

\section{Tales from Konjaku Monogatari-shu on Buddhism in China}

Foreword, translation and comments by Maya V. Babkova (Institute of Oriental Studies, Russian Academy of Sciences)

The paper presents the translation of selected stories of chapters 6 and 7 of Konjaku Monogatari-shū, the biggest collection of setsuwa tales. Both chapters deal with the history of Buddhism in China. But the narrative in chapter 6 sets the major steps which are related to the process of the transmission of the Buddhadharma from India to China, and chapter 7 proceed and elaborates on one of its key topics: the veneration of the holy scriptures. The choice of tales to be translated was made so as to show the variety of topics and the specific features of the narrative in chapters 6 and 7 of Konjaku Monogatari-shū.

Keywords: Japanese literature, Konjaku Monogatari-shu, setsuwa tales, Buddhism, China

\section{Вступительное слово}

На протяжении всей истории Японии размышления ее жителей о своей стране развивались в непрерывном соотнесении с опытом других государств восточноазиатского региона, в первую очередь, Китая. Но если для многих японских традиций китайская культура была родительской в полном смысле этого слова (то есть именно в Китае эти традиции возникли и оформились, и лишь после были восприняты японцами), то в отношении буддизма Китай и Япония находятся почти в сходной позиции. В Китае буддизм появился раньше, и большинство стран Дальнего Востока восприняли его в

* БАБКОВА Майя Владимировна, кандидат философских наук, научный сотрудник Центра японских исследований Института востоковедения РАН, старший научный сотрудник Школы актуальных гуманитарных исследований Российской академии народного хозяйства и государственной службы при Президенте Российской Федерации.

E-mail: maya.babkova@gmail.com

Работа выполнена при финансовой поддержке гранта РФФИ. Проект № 18-011-00558.

(C) Бабкова М.В., 2020 
китаизированной форме, но родиной его осталась Индия.

К XII в. буддийское вероучение глубоко проникло во все слои японского общества. Примерно в это время, на стыке двух исторических эпох - Хэйан и Камакура, было составлено «Собрание стародавних повестей» («Кондзяку моногатари сю:»), самый большой из сборников сэцува - японских поучительных рассказов. Истории, вошедшие в сборник, с трудом поддаются обобщению: они разнятся и по длине, и по персонажам, и по характеру событий, и по степени назидательности, и по эмоциональному заряду. Но при этом, во-первых, в «Кондзяку» у рассказов есть общие формальные признаки: все они начинаются со слов «в стародавние времена...» и заканчиваются фразой «так передают этот рассказ». Во-вторых, сборник имеет четкую структуру, где каждая часть образует композиционное единство с остальными и одновременно имеет свои лейтмотивы.

Общий принцип организации сборника отражает географический и исторический путь распространения буддизма из Индии времен Будды Шакьямуни в Японию XII в. Первая из трех больших частей называется «Индия» (свитки 1-5), вторая - «Китай» (свитки 6-10), третья - «Наша страна» (Япония, свитки 11-31). Не все свитки на самом деле существуют: три отсутствуют (8-й, 11-й и 21-й). Точно так же опущены и некоторые рассказы, и фрагменты текста внутри отдельного рассказа (в переводе ниже пример такого пропуска есть в рассказе 6-1). Они могли не дойти до наших дней, но более вероятно, что составители оставляли пробелы сознательно. Так или иначе, даже с учетом пропусков, рассказы компонуются внутри свитков, свитки - внутри частей, а части продолжают друг друга. В каждом из трех больших разделов за «буддийской» частью следует «мирская», где сверхъестественных сил мало, либо вообще нет, либо они представлены персонажами из китайской или японской мифологии. Но 6-й и 7-й свитки, рассказы из которых здесь публикуются, не таковы: они посвящены Закону Будды в Китае.

В 6-м свитке освещается история передачи буддизма из Индии в Китай. Составители «Кондзяку» собрали 48 рассказов, как четки, где каждая отдельная история-бусина повествует о какой-то зримой и осязаемой составляющей понятия «Закон Будды». Это буддийские учителя - наставники из Индии, или съездившие туда и обретшие мудрость китайцы. Это буддийские книги - свитки с сутрами и мандалами. Это образы будд - прежде всего статуи, но и чудодейственные останки, шарира. В рассказах описано, как проповедников встречали в Китае, каких успехов им удавалось достичь в демонстрации могущества Закона Будды; при каких чудесных обстоятельствах привозили книги и статуи, как и почему китайцы начинали их чтить. Вторая часть свитка в основном содержит истории о том, к чему приводит почитание (или пренебрежение почитанием) буддийских святынь: статуй и сутр. Чаще всего речь идет о смерти и о том, как к ней подготовиться, чтобы обрести перерождение в буддийском раю: нужно читать и переписывать сутры, мастерить и чтить подношениями образы будд, не убивать животных. Как быть, если смерть уже наступила, а подготовиться человек не успел или не посчитал нужным, - таких рассказов очень много, и в них всегда действует загробный судья, царь Яма. В его канцелярии записаны все дела живых, но он благоговейно склоняется перед буддийскими праведниками: если они заступаются за грешника, Яма никогда не перечит им. Наконец, как избежать смерти: например, благочестивый генерал из рассказа 6-14 выжил, когда ему в лоб попала молния, ибо всю силу удара приняла на себя статуя Будды. В нескольких рассказах речь идет о долголетии, богатстве, исцелении. Независимо от конкретного сюжета составители в 6-м свитке «Кондзяку», как и в других свитках, показывают, как ученые мужи и простой народ осмысляли бытовую реальность сквозь призму буддийских представлений.

Следующий, 7-й свиток примыкает к шестому, развивая и одновременно сужая одну из главных тем: почитание священных текстов. Формально рассказов в свитке тоже 48, но восемь из них (с 33-го по 40-й) пропущены. Первая часть свитка - истории о почитании «Большой сутры праджня-парамиты», одного из главных текстов буддизма махаяны. Кроме того, речь идет об «Алмазной сутре», «Сутре о человеколюбивых государях», «Сутре о великой нирване». Дальше рамки историй еще больше сужаются: 20 рассказов, ровно половина всего свитка, посвящены чудесам «Лотосовой сутры» (в японской части «Кондзяку» этой же теме отведена половина 12-го и весь 13-й свиток). «Лотосовая сутра»- текст, сравнимый по значимости с Библией и для Китая, и для Японии. В нем Будда Шакьямуни проповедует возможность избавления от страданий для всех живых 
существ, непреложное действие закона воздаяния и путь милосердия, на который может и должен встать всякий человек. В рассказах 7-го свитка «Лотосовая сутра» и другие буддийские писания помогают избавиться от бедности, болезни, изгнать демонов или спасти их самих от горькой участи быть демонами, но главное продвинуться по Пути Будды и выйти из круга рождений и смертей.

Перевод рассказов выполнен по следующему изданию: [1].

\section{6-1. Рассказ о том, как во времена первого императора Цинь \\ в Китай прибыл индийский монах}

В стародавние времена в Китай, где тогда правил первый государь Цинь ${ }^{1}$, прибыл индийский монах. Звали его Ши Ли-фан ${ }^{2}$. С ним было восемнадцать мудрецов, а еще они привезли книги святого учения.

Государь увидел все это и спросил: «Кто вы такие? Из какой страны? На вид чудные - волос на голове нет, лысые; одеты, как людям не пристало». Ли-фан в ответ рассказал вот что: «В Западной стране жил великий царь по имени Шуддходана. У него был единственный сын, наследник. Его звали царевич Сиддхартха. Он отверг мирскую жизнь, покинул свой кров и ушел в горы. Там он шесть лет истязал себя трудным подвижничеством и обрел наивысший Путь. Его стали называть Будда Шакьямуни. Больше сорока лет он самыми разными способами растолковывал Закон всем живым существам. Он обращал к Учению живые существа, каждый раз подстраивая объяснения под слушателей, а в конце концов ушел в нирвану в возрасте восьмидесяти лет. Но после его ухода одна из четырех частей его общины ${ }^{3}$ [пропуск]. Я прибыл передать Учение Будды так, как он сам его толковал.

Царь рек: «Ты называешь себя учеником Будды, но я знать не знаю никакого Будды и никаких “бхикшу"4. Смотреть на тебя противно. Тебя нужно изгнать, но я не стану отсылать тебя обратно, а посажу в темницу и сурово накажу. Тех же, кто впредь станет произносить

\footnotetext{
${ }^{1}$ Имеется в виду Цинь Ши Хуанди. Период правления - 247-210 до н.э.

2 Монахи из общины Будды Шакьямуни брали себе «фамилию» Ши (Шакья).

3 Четыре группы учеников Будды: монахи и монахини, миряне и мирянки.

${ }^{4}$ Бхикшу (санскр.) - монах, принявший полные обеты.
}

такие безумные речи, буду казнить». Он позвал стражников и велел им бросить [приезжих] в темницу. Стражники, исполняя высочайшую волю, посадили монахов в тюрьму за несколькими дверьми, где содержали самых злостных преступников.

Тогда Ли-фан заплакал, запечалился, вскричал: «Мы прибыли в эту далекую землю передать Учение и Закон Будды. Теперь же, из-за того, что этот злой царь еще ничего не знает о Законе Будды, он нас так сурово карает. О горе! О, мой великий учитель Шакьямуни, Пришедший своим путем, хоть ты давным-давно ушел в нирвану, ты обладаешь чудесной силой - взгляни же на нас сейчас! Прошу, избавь нас от этих мучений!» Так он помолился от всего сердца и лег. Настала ночь, и вдруг, откуда ни возьмись, в воздухе возник Будда Шакьямуни, Пришедший своим путем. Он был ростом в один дзё и шесть сяку и от него исходило багряно-золотое сияние ${ }^{6}$. Он пнул дверь темницы, та рассыпалась, и он вошел, а затем вышел наружу вместе с Ли-фаном. И восемнадцать мудрецов так же сбежали.

Тогда и множество преступников, кто был заключен в темнице, раз ее разрушили, разбежались во все стороны, кто куда хотел.

А один из стражников в это время услышал в небе страшный грохот. Он удивился, а когда вышел посмотреть, то увидел золотую фигуру человека ростом выше дзё ${ }^{7}$ [От человека исходило золотое сияние, он прямо по воздуху подлетел к дверям темницы, пнул их, вышиб, вошел ... стражник ужасно испугался. Так и вышло, что Закон Будды, который хотели передать из Индии в Китай, в тот раз распространить не удалось. Его передали уже позже, при династии Поздняя Хань, при государе Мин-ди ${ }^{8}$.

В старину, еще при Чжоу ${ }^{9}$, буддийские книги уже передавали в те края. И царь Ашока построил пагоду в тех края ${ }^{10}$. Но когда первый государь Цинь сжег все писания, буддийские книги тоже сгорели. Так передают этот рассказ.

\footnotetext{
5 T.e. 4,8 м.

${ }^{6}$ Различали пять видов золота, из которых багряное (紫磨黄金, от санскр. суварна) - самое драгоценное.

${ }^{7} 1$ дзё = 3,03 м.

${ }^{8}$ Период правления - 58-75 гг. н.э., второй император Восточной династии Хань.

9 При династии Чжоу, с 1045 по 221 гг. до н.э. Согласно одному из буддийских преданий, Лао-цзы и Конфуций при Чжоу были учениками Будды.

${ }^{10} \mathrm{~B}$ «Кондзяку» об Ашоке и его пагодах говорится в рассказах 4-го свитка.
} 
6-3. Рассказ о том, как во времена государя У-ди династии Лян

в Китай пришел Бодхидхарма

В стародавние времена в Индии жил святой мудрец, учитель Бодхидхарма, а у него был ученик, монах по имени Буддхаяша ${ }^{11}$. Бодхидхарма велел Буддхаяше: «Отправляйся сейчас же в Китай и передай им Закон Будды». Буддхаяша сделал, как ему было сказано: сел на корабль и приехал в Китай. Но когда он собрался передавать Закон, оказалось, что в Китае уже есть несколько тысяч бхикшу и они подвижничают каждый по-своему. Они выслушали, какой Закон проповедовал Буддхаяша, но ни один не поверил ему, и в конце концов монахи прогнали его. Буддхаяше пришлось бежать, и он укрылся в горах Лушань, в храме Дунлиньсы.

В горах Лушань жил святой мудрец, почтеннейший Великий учитель Юань. Когда он узнал, что приехал Буддхаяша, то пригласил его к себе и стал расспрашивать:

- Ты ведь приехал из западных стран, как ты толкуешь Закон Будды? Какое учение ты хотел распространить на нашей земле и почему тебя изгнали?

Буддхаяша вместо ответа сжал кулак и раскрыл его, а потом спросил:

- Понимаешь ли ты, что это значит?

Учитель Юань понял: Буддхаяша сжатым кулаком показал заблуждения и страдания живых существ, раскрытой ладонью показал просветление, а сказать хотел, что страдания и просветление суть одно.

Буддхаяша оставался в тех местах до самой смерти. Его учитель, Бодхидхарма, был в далекой Индии, но чудесным образом узнал о кончине своего ученика, сам сел на корабль и переплыл по морю в Китай. В то время правил государь У-ди династии Лян. При нем построили огромный монастырь, отлили множество статуй будд, возводили пагоды, переписывали множество сутр. Вот государь и думал: «Заслуги мои огромны. Если бы я показал все, что сделал, какому-нибудь мудрому монаху, он бы наверняка высоко оценил мои дела. Где бы взять у нас в стране мудрого и достойного человека?» У-ди разыскивал такого человека, и кто-то ему

${ }^{11}$ Буддхаяша (V в.) - переводчик буддийских текстов, уроженец Кашмира. Знаменит, среди прочего, тем, что перевел на китайский текст «Дхармагуптака-виная», который впоследствии получил наибольшее распространение в Китае и Японии как «Четырехчастный устав». донес: «Из Индии недавно прибыл один святой мудрец по имени Бодхидхарма. Он мудрый и достойный, глубокомудрый старец». У-ди, слыша это, обрадовался и подумал: «Я позову этого Бодхидхарму, покажу ему монастырь, статуи, сутры и все остальное, что он, конечно, высоко оценит. А я тогда узнаю у него, как еще можно обрести достойные заслуги, и взращу еще более мощные корни блага $\left.{ }^{12}\right\rangle$.

Рассудив так, У-ди послал за Бодхидхармой, и тот, получив приглашение, сразу же явился. Государь показал ему монастырь, храмовые залы, пагоды, статуи, сутры и все прочее, а потом спросил:

- Я возводил храмовые залы и пагоды, переправлял людей [к Учению], переписывал сутры, создавал образы будд. Каковы мои заслуги?

Великий учитель Бодхидхарма ответил:

- Все это не приносит заслуг.

У-ди был уверен, что когда учитель увидит, каков его монастырь, непременно вознесет ему великую хвалу, и такой ответ его совершенно обескуражил. Он ничего не понял:

- Как же так, почему все это не приносит заслуг?

Бодхидхарма ответил:

- Когда кто-то строит пагоды, храмы и думает, что ему зачтутся выдающиеся благие дела, это преходящие дела, истинной заслуги в них нет. Истинной заслугой называется вот что. Когда кто-то понимает, что в этом теле он есть чистейший Будда, выросший из семени просветления, и проявляет [эту свою природу], тогда он создает себе истинную заслугу. А твои дела не таковы, потому и не приносят заслуг.

Так сказал Бодхидхарма, и У-ди не понравился его ответ. Государь подумал: «Почему он так говорит? Мои заслуги несравненны, я уверен. Раз он меня бранит, он наверняка замыслил недоброе». У-ди разозлился и прогнал Бодхидхарму прочь.

Тогда Бодхидхарма взял свой посох с кольцами и ушел жить в горы под названием ... . Там он повстречал будущего учителя созерцания Хуэй-кэ ${ }^{13}$. Бодхидхарма в полной мере передал ему Закон Будды. После этого Бодхидхарма в тех краях и умер. Монахи из его общины положили его в гроб, гроб поставили в усыпальницу. А через четырнадцать дней один человек, государев посланник по имени Сун Юнь, путе-

12 Деяния, которые с неизбежностью становятся причинами благих последствий для того, кто их совершил, или тех, кому он «подарил» эти заслуги от них.

13 Хуэй-кэ (487-593) - первый китайский ученик Бодхидхармы, второй китайский патриарх Чань. 
шествуя по делам, поднялся на горы Кунлинь ${ }^{14}$ и повстречал монаха-иноземца. У того монаха только на одной ноге была соломенная сандалия, другая нога была босой, а сказал он Сун Юню вот что:

- Тебе надобно знать: твой государь сегодня помер.

Услышав это, Сун Юнь вынул бумагу и записал месяц и день. Через месяц Сун Юнь вернулся в столицу и узнал, что государь действительно скончался. Оказалось, день и месяц точно те, что были записаны на бумажке. Сун Юнь задумался, кто же был монах-иноземец, который известил его о кончине государя еще в горах Кунлинь, и понял, что повстречал Учителя Бодхидхарму. Он взял с собой столичных чиновников, позвал монахов из общины Бодхидхармы и отправился с ними со всеми туда, где Бодхидхарма был захоронен, узнать, верна ли догадка. Они открыли гроб и увидели, что тела Бодхидхармы нет: внутри лежала только одна соломенная сандалия. Тут все поняли: монах-иноземец с гор Кунлинь точно был Бодхидхармой, он ведь был в одной соломенной сандалии. Бодхидхарма вернулся в Индию, а одну свою сандалию оставил, чтобы китайцы узнали, кто он.

С тех пор все в Китае узнали, что Бодхидхарму не зря зовут святым глубокомудрым старцем. Все стали его чтить и уважать. Учитель Бодхидхарма - третий сын царя великой страны брахманов. Так передают этот рассказ.

\section{6-12. Рассказ о том, как в Китае}

Фа-цин из храма Игуаньсы ожил

благодаря статуе Будды Шакьямуни

В стародавние времена в Китае был храм Игуаньсы, а в нем жил монах по имени Фа-цин. Шел третий год Кайхуан ${ }^{15}$, когда Фа-цзин задумал смастерить лаковую статую Шакьямуни высотой в один дзё и шесть сяку ${ }^{16}$. Но потом Фацин внезапно умер, не успев закончить работу.

И в тот же день в храме Фачансы скончался монах по имени Да-чжи. Через три дня Да-чжи ожил и рассказал братии вот что.

- Когда я умер, я попал во владения царя Ямы и встретил Фа-цина из храма Игуаньсы. На вид Фа-цин был чем-то сильно огорчен, а пока я на

${ }^{14}$ Сун Юнь (даты жизни неизвестны) в 518 г. совершил путешествию в Среднюю Азию и привез оттуда копии буддийских сутр для императора Северной Вэй Сяо Мина (прав. 516-528).

15583 г.

16 T.e. 4,8 м. него смотрел, появился другой весьма почтенный монах, предстал перед царем и обратился к нему с такими словами: «Этот Фа-цин мастерил мою статую и не успел закончить. Почему он умер?» Яма спросил одного из своих приближенных: «У покойника Фа-цина осталась еще жизнь?» Тот отвечал: «Жизнь Фа-цина еще не иссякла, но запасов еды больше нет». Тогда царь повелел: «Выдайте Фа-цину листьев лотоса, чтобы он мог прожить, пока не завершит свое благое дело». И Фа-цин тут же исчез.

Bce это Да-чжи поведал собратьям монахам. Они же, выслушав его, отправились в храм Игуаньсы проверить, правда это или нет. Оказалось, что Фа-цин жив и Да-чжи ни в чем их не обманул.

С тех пор как ожил, Фа-цин постоянно питался листьями лотоса, и только насладившись их вкусом, принимался за остальную еду.

Фа-цин закончил работу над статуей и через несколько лет умер. Образ Шакьямуни излучал свет, и все черты Шакьямуни Фа-цин передал точно ${ }^{17}$. Говорят, статуя и поныне стоит в храме Игуаньсы. Так передают этот рассказ.

\section{6-17. Рассказ о том, как в Китае Дао Юй из храма Кайцзюэсы изваял статую Будды Амиды и переродился в Чистой Земле}

В стародавние времена в Китае при династии Суй ${ }^{18}$ был храм Кайцзюэсы, а в нем тогда жил монах по имени Дао-юй. Много лет он только и делал, что произносил памятование о Будде Амиде, а больше ни о чем не думал. А еще он вырезал из сандалового дерева фигурку Будды Амиды в три цуня ${ }^{19}$ величиной.

И вот Дао-юй внезапно умер. Семь дней его не хоронили. Через семь дней он ожил и рассказал вот что.

- Когда я умер, я первым делом повстречал величавого, благородного на вид человека у пруда Семи драгоценностей ${ }^{20}$. Он трижды обошел вокруг лотосов, и на третий раз один бутон

${ }^{17}$ Список черт Будды в «Стародавних повестях» есть в свитке 1, традиционно он включает 32 признака великого человека: нарост на голове (ушнишу), длинные мочки ушей, перепонки между пальцами ног и др.

18 581-618 гг.

19 T.e. 10 см.

20 Такие пруды описаны в текстах о стране Вечной Радости, Чистой земле Будды Амитабхи. Пруды наполнены чистейшей водой, и в них цветут лотосы. 
раскрылся. Тогда человек вошел в пруд и сел на тот цветок. Поглядев на него, и я так же, как и он, стал обходить лотосы, но ни один бутон не раскрылся. Наоборот, все цветы, каких я касался рукой, увядали и осыпались.

Тут передо мной появился Будда Амида и сказал: «Тебе нужно на время вернуться обратно, в твою страну, и от всего сердца покаяться во грехах. А тело твое нужно омыть в благовонной воде. Когда взойдет утренняя звезда, я приду за тобой. Ты вырезал мой образ из дерева, но как ты выбрал его величину? У кого сердце велико у того и творение велико, у кого сердце маленькое - у того и творение маленькое». Будда закончил говорить, и его образы заполнили все небо.

После этого Дао-юй, как научил его Будда, омыл тело в благовонной воде и от всего сердца покаялся во грехах. Своим людям Дао-юй велел: «Почтите Будду Амиду памятованием ради моего спасения!» - и они по его просьбе произносили молитву, памятуя о будде.

Когда взошла утренняя звезда, к Дао-юю явился Будда в превращенном теле, люди Дао-юя слышали и видели его, а потом Дао-юй умер.

Люди с уважением говорили: без сомнения, Дао-юй возродился в стране Высшей Радости. Так передают этот рассказ.

\section{6-34. Рассказ о том, как в Китае послушник из храма Кунгуаньсы мечтал о Мире-Вместилище Цветов Лотоса и выжил}

В стародавние времена в Китае в храме Кунгуаньсы жил послушник по имени Дин-шэн. Хоть он и считался послушником, монашеский устав нарушал, сутры же и вовсе не читал.

Однажды Дин-шэн услыхал, как некий монах проповедует о Мире-Вместилище Цветов Лотоса ${ }^{21}$. Ему так понравилось, что с тех пор он только и делал, что мечтал о той земле.

Но поскольку послушник в монашеских делах был нерадив до крайности, то когда он умер, попал в ад красных лотосов 22 . Тем не менее, увидев ад, Дин-шэн решил, что это и есть Мир-Вместилище Цветов, и на радостях пропел: «Слава Чудесному Краю, Миру-Вместили-

Семь драгоценностей - это золото, серебро, лазурит, хрусталь, агат, рубин, изумруд.

${ }^{21}$ Согласно «Сутре о величии цветка» («Аватамсака-сутра»), это Чистая земля Будды Вайрочаны, которая покоится на огромном цветке лотоса.

${ }^{22}$ Седьмой из восьми холодных адов или десятый из десяти холодных адов. щу Цветов». И тут [окружавший послушника] ад вдруг преобразился и действительно стал Миром-Вместилищем Цветов. А все грешники, кто слышал, как послушник поет «Слава Чудесному Краю, Вместилищу Цветов», воссели на цветах лотоса.

Демоны-стражи, увидав такое чудо, донесли царю Яме. Царь же сказал:

- Вот она, великая и непостижимая разумом сила «Сутры о величии цветка!

И толкуя эти слова, произнес гатху:

Благоговейно прибегаю-возвращаюсь

К непостижимой «Сутре цветочного убранства»!

$\mathrm{Bce}$, кто услышит хотя бы название этой сутры

Или одно четверостишие из нее,

Смогут избежать ада,

Смогут сбросить узы воздаяния;

Для тех людей темницы и все, что их окружало,

Превратятся в Мир-Вместилище Цветов,

И они обнаружат,

что сидят на драгоценных цветах лотоса.

Все это - как ад превратился в Мир-Вместилище Цветов и как все грешники оказались сидящими на цветах лотоса, - послушник видел сам, а когда прошли день и ночь, он ожил и рассказал об этом. С тех пор он обрел чудесные силы ${ }^{23}$, сердце его устремилось к просветлению, и он совершил множество благих дел. А куда он потом делся, никто не знает. Так передают этот рассказ.

\section{6-43. Рассказ о том, как в Китае}

Тань Луань ${ }^{24}$ сжег даосский канон и возродился в Чистой Земле

В стародавние времена в Китае при династии Ци ${ }^{25}$ жил монах по имени Тань Луань. Он изу-

${ }^{23}$ Научился летать, читать мысли, обрел знания о прошлых перерождениях и пр.

24 Тань Луань (476-572) считается первым из пяти патриархов традиции почитания Чистой Земли. Жил на севере Китая, но из-за проблем со здоровьем отправился на юг изучать даосское учение о достижении бессмертия. Потом Тань Луань вернулся, встретился в Лояне с Бодхиручи (?-527), знаменитым переводчиком буддийских текстов (знатоком «Трех Хранилищ» буддийского канона - сутр, уставов и трактатов), и тот убедил его в превосходстве «Сутры о видении будды по имени Неизмеримое Долголетие» («Амитаюр-дхьяна-сутра»). С тех пор Тань Луань развивал учение о Чистой Земле, хотя многое в его мировоззрении осталось от даосского периода.

25 Тань Луань жил в государстве Северная Вэй, которое потом раскололась на Западную и Восточ- 
чил и хранил китайский «Канон бессмертных» в десяти свитках ${ }^{26}$. Читая его, Тань Луань глубоко уверовал, что учение о продлении жизни и достижении бессмертия - наивысшее. Он укрылся в тайном месте и жил там отшельником, изучал, как стать бессмертным.

Потом Тань Луань повстречал Бодхиручи, знатока Трех Хранилищ. Тань Луань спросил его:

- Есть ли в Законе Будды что-то, что превосходило бы учение о продлении жизни и достижении бессмертия, которое изложено в нашем китайском «Каноне бессмертных»?

Бодхиручи удивился и ответил:

- Думаешь, где-то на этой земле правда есть учение о продлении жизни и достижении бессмертия? Ведь, сколь ни растягивай земную жизнь, когда-нибудь она точно закончится, сомнений нет!

С этими словами Бодхиручи вручил Тань Луаню «Сутру о видении будды по имени Неизмеримое Долголетие» и добавил:

- Если ты освоишь, подвижничая, Закон этого великого бессмертного ${ }^{27}$, сможешь навсегда избавиться от рождений и смертей и обретешь освобождение.

Выслушав Бодхиручи, Тань Луань горько раскаялся и немедленно сжег «Канон бессмертных». Много лет спустя, когда Тань Луань понял, что его жизнь подходит к концу, он взял в руки курильницу для благовоний, повернулся лицом к западу и скончался с молитвой к будде на устах. В это время с западной стороны в небе зазвучала чудесная музыка, а через некоторое время прекратилась. Люди, кто ее слышал, так передают этот рассказ.

\section{6-48. Рассказ о том, как в Китае мальчик услышал «Сутру о долгой жизни» \\ и обрел долголетие}

В стародавние времена в Китае при танском Сюань-цзуне, ближе к концу годов Кай-юань ${ }^{28}$, жил один гадатель: ему было равно легко, что показать ладони, что назвать срок жизни человека.

ную Вэй. Он оказался в Восточной Вэй, на месте которой в 550 г. было образовано государство Северное Ци (550-577).

${ }^{26}$ Книги даосского канона.

27 Здесь кит. дайсян - не даосский бессмертный, а Будда Амитаюс, Неизмеримое долголетие.

28 Девиз правления танского императора Сюань-цзуна с 713 по 741 гг.
Как-то раз гадатель стоял в воротах храма Цзышэнсы и услышал за воротами чей-то голос. По голосу было ясно, что человеку осталось жить всего один день. Гадатель обеспокоился, поскорей вышел наружу и увидел стройного, миловидного отрока. «Сколько тебе лет?»- спросил гадатель, и паренек ответил: «Тринадцать». Больше гадатель не стал ничего говорить, хотя и глубоко опечалился, вернулся в храм.

На следующий день гадатель вновь повстречал того же отрока неподалеку от храма. Теперь [было видно, что тому] предстоит прожить еще больше семидесяти лет. «Ну надо же!» - подумал гадатель и обратился к парню с вопросом:

- Вчера, когда я встретил тебя, тебе оставалось прожить всего один день, но сегодня я вижу, что тебе суждено жить еще долго-долго, больше семидесяти лет. Какие корни блага ты взрастил, чтобы так продлить срок жизни?

А отрок ответил:

- Сегодня я ночевал в храме и слышал, как кто-то из монахов читал «Алмазную дхарани-сутру о долголетии» ${ }^{29}$. Больше я ничего не делал.

«Вот она, непостижимая сила Закона Будды!» - восхитился гадатель. - «Мелкому уму ее не измерить!» И ушел восвояси.

Задумаешься обо всем этом, и правда, похоже, мальчик обрел заслугу от того, что случайно услышал сутру. А если переписывать ее сознательно, сколько благой силы получишь! Так передают этот рассказ.

\section{7-1. Рассказ о том, как император Сюань-цзун впервые совершил подношение «Большой сутре праджня-парамиты»}

В стародавние времена в Китае, при танском государе Сюань-цзуне, Сюань-цзан, Знаток Трех Хранилищ, перевел «Большую сутру праджня-парамиты» ${ }^{30}$. В храме Юйхуасы казначей Цзи-чжао ${ }^{31}$, Цин-хэ и другие монахи записали перевод. Когда государю доложили,

29 Яп. «Конго: дарани дзё:мё:кё:» - одна из сутр тайного учения.

${ }^{30}$ Сюань-цзан (602-664) - одна из главных фигур в процессе передачи буддизма в Китай, переводчик и проповедник. На самом деле он работал при танском Тай-цзуне (период правления - 627-649 гг.).

${ }^{31}$ Казначей, здесь - санскр. кармадана, третья по значимости должность в монастыре, заведующий хозяйством. 
что работа закончена, он очень обрадовался и решил провести собрание с подношением даров. Под зиму третьего из годов Луншо, в тридцатый день десятого месяца, зал Счастливого Долголетия украсили драгоценными знаменами, балдахинами, приготовили самые разные дары. Все было устроено чудесно, прекраснее некуда.

В тот день торжественно встречали перевод «Большой сутры праджня-парамиты». Книгу перенесли из зала Величавого Успеха в зал Счастливого Долголетия и устроили великое собрание: читали и толковали сутру, подносили дары [монашеской общине]. Церемония была самая величественная.

«Большая сутра праджня-парамиты» сияла так, что и вблизи, и вдалеке все было освещено. С неба падали чудесные цветы, в воздухе разливался необычайный аромат. И все, начиная с государя, и высокие сановники, и прочий чиновный люд - все восхищались, и каждый про себя дивился таким чудесам. Сюань-цзан же сказал собравшимся: «Все в точности так, как толкует сутра. “Те, кто ищет учение Великой колесницы на всех четырех сторонах света, будь то цари, их министры или кто угодно среди четырех групп учеников, если они перепишут эту сутру, примут ее и будут ее держаться, будут читать ее вслух и распространять ее учение, все они обретут рождение на небесах и в конце концов выйдут из круга перерождений”. Так говорится в сутре, и нам ни в коем случае нельзя забывать эти слова».

Позже Цзи-чжао приснилось, как тысяча будд с небес ${ }^{32}$ все в один голос произнесли гатху:

«Праджня-сутра» - чудесное писание в Законе Будды, Главнейшее среди всех прочих писаний.

Кто услышит ее - обретет наивысшее просветление. Кто примет ее и сохранит, будет читать и переписывать, Кто почтит ее хоть одним цветком, хоть одним ароматом Для каждого из этих людей она станет прибежищем, И они непременно избавятся от страданий рождений и смертей.

Так они проповедовали, а как закончили, Цзи-чжао проснулся.

Когда об этом рассказали Сюань-цзану, он объяснил: «Все так. В сутре [говорится], что явятся тысяча будд».

32 Тысяча будд есть в прошлом, настоящем и будущем. Среди будд прошлого - Кашьяпа, четвертый в настоящей кальпе - Шакьямуни, а когда наступит будущая кальпа, придет Майтрейя.
Так началось почитание «Большой сутры праджня-парамиты». Потом люди по всей стране стали подносить этой сутре дары, принимать и удерживать ее учение, читать ее вслух и так чтить. Она сотворила множество чудес для тех, кто завязал с ней связь, и ее чтят и поныне. Так передают этот рассказ.

\section{7-4. Рассказ о том, как в Китае Сэн-чжи прочел \\ по памяти двести свитков}

«Большой сутры праджня-парамиты»

В стародавние времена в Китае в столице жил монах по имени Сэн-чжи.

Его матери приснилось, будто она проглотила курильницу для благовоний, а потом она забеременела и родила Сэн-чжи. Едва родившись, Сэнчжи уже умел произносить название «Праджня-сутры». Люди еще тогда удивлялись, а Сэн-чжи к двадцати годам мог по памяти прочесть двести свитков из сутры. Только вот выучить остальное ему никак не удавалось. С тех пор, как он вышел из дому, он взял себе за правило каждый день читать вслух сотню свитков сутры.

Сэн-чжи думал: «Я могу прочесть по памяти двести свитков “Большой сутры праджня-парамиты”, но никак не могу выучить остальное и не понимаю, по какой причине. Раз так, буду молиться, чтобы узнать, в чем дело».

И вот Сэн-чжи приснился сон. К нему пришел монах и сказал:

- В прошлой жизни ты был презренным волом, и твои хозяева на тебе повезли двести свитков «Большой сутры праджня-парамиты». По дороге в храм тебе пришлось месить ногами глубокую грязь, ты пробирался через нее с трудом. Благодаря этому ты обрел такую заслугу, что переродился человеком, смог стать монахом и выучить наизусть двести свитков «Большой сутры праджня-парамиты». А поскольку с остальными свитками сутры ты не завязал связь, то дальше ты и не можешь запомнить. В следующий раз ты переродишься в земле Будды Громового Раската ${ }^{33}$.

Тут Сэн-чжи проснулся. Теперь он понял, что к чему, и был благодарен своей прошлой жизни.

Не зря, значит, люди уверены: все доброе и дурное происходит с нами в зависимости от того, какие связи мы завязали в прежних жизнях. Так передают этот рассказ. хьей.

${ }_{33}^{3}$ Будда Громового Раската соотносится с Акшоб- 


\section{7-7. Рассказ о том,}

как в Китае монах читал

«Большую сутру праджня-парамиты»

и получил подношения с небес

В стародавние времена в одной из китайских провинций был горный храм, а в нем жил бхикшу. Много лет подряд он читал вслух «Большую сутру праджня-парамиты».

И вот как-то раз ночью к монаху прилетел небожитель и преподнес ему сладкой росы с небес ${ }^{34}$. Монах принял дар и спросил:

- А у вас на небесах есть «Махапраджняпарамита-сутра»?

- Есть, - ответил небожитель.

- Почему же тогда ты прилетел ко мне с подношением? - спросил монах.

- Я прилетел почтить Закон, - отвечал небожитель. - И потом, небесная «Большая сутра праджня-парамиты» - это слова, которые передают небесные боги. А людям известна правильная «Большая сутра праджня-парамиты», как ее проповедовал сам Будда. Вот почему я прилетел и принес тебе подношение.

Тогда монах спросил:

- А у вас на небесах есть те, кто принял и удерживает учение «Большой сутры праджня-парамиты»?

- Нет, - ответил небожитель. - Ведь у нас все только и делают, что наслаждаются. Да и во всех прочих краях таких нет. Только на Джамбудвипе, где прорастают корни Великой колесницы, можно избавиться от страданий, приняв и удерживая благое учение «Большой сутры праджня-парамиты».

- Скажи, - продолжил спрашивать монах, среди вас, небожителей, только ты один оберегаешь тех, кто принял и удерживает «Большую сутру праджня-парамиты»?

- Нас таких восемь миллиардов, - ответил дух. - Мы оберегаем людей, принявших и удерживающих «Большую сутру праджня-парамиты». Все мы спускаемся в мир людей и оберегаем тех, кто принял и удерживает «Большую сутру праджня-парамиты». На самом деле почтить человека, который слышал хоть один стих из сутры - то же самое, что почтить Будду. Раз так, то забрасывать это дело и отказываться от него ни в коем случае нельзя.

Сказал так небожитель и исчез. Вот почему нужно твердо знать: если кто из людей примет и будет удерживать «Большую сутру праджня-парамиты», будет ее распевать и переписы-

\footnotetext{
34 Амриты, пищи небесных богов.
}

вать, к нему непременно придет небожитель и будет оберегать такого человека. Так передают этот рассказ.

\section{7-12. Рассказ о том,}

как в танском Китае монах поселился в храме на горе Тайшань и читал там «Сутру о человеколюбивых государях»

В стародавние времена в Китае при танском государе Дэ-цзуне, в девятнадцатый год Чжэнь-гуань ${ }^{35}$, жил один монах. Как его звали и откуда он был, неизвестно. Этот монах поселился в храме Хозяина горы Тайшань ${ }^{36}$ и прочел там четыре строфы о непостоянстве ${ }^{37}$ из нового перевода «Сутры о человеколюбивых государях» ${ }^{38}$.

Когда наступила ночь, монаху приснился сам Хозяин горы Тайшань и рассказал вот что:

- Я слышал эту сутру давным-давно, еще до времен Будды. Она и по словам, и по смыслу совпадает с переводом Кумарадживы. Я слушал, как ты читал, и рад, что тело и сердце мои очистились. И все-таки хоть у этого нового перевода слог изящный, но смысл слабый, скудный. Так что тебе нужно следовать старому переводу.

И тут Вайшравана ${ }^{39}$ дал монаху ту сутру, и он проснулся.

После этого монах стал читать и старый перевод. Так передают этот рассказ.

\section{7-26. Рассказ о том, как в Китае \\ Цуй Янь-у, наместник Вэйчжоу, знал о своей прошлой жизни \\ и чтил «Лотосовую сутру»}

В стародавние времена в Китае при династии Суй в годы Кайхуан ${ }^{40}$ наместником Вэй-

35 Дэ-цзун правил с 780 по 805 гг., с 785 по 805 гг. - под девизом Чжэньюань (貞元). А под девизом Чжэньгуань правил с 627 по 649 гг. император Тай-цзун.

36 Даосское божество, которое управляет жизнью и смертью людей; в буддизме стал помощником царя Ямы. О его почитании в Японии (под именем Тайдзан Фукун) см. в статье М.С. Коляды в настоящем выпуске журнала.

${ }^{37}$ Парные строфы из «Сутры о человеколюбивых государях», где обсуждаются непостоянство, страдание, пустота и отсутствие $Я$.

${ }^{38}$ Перевод Букуна здесь противопоставлен старому переводу Кумарадживы.

${ }^{39}$ Один из четырех небесных царей, божество-охранитель «Сутры о человеколюбивых государях».

40 581-600 гг., первый девиз правления династии Суй (581-618 гг.). 
чжоу был человек по имени Цуй Янь-у родом из Болина ${ }^{41}$.

Янь-у объезжал вверенный ему край. Когда он прибыл в одну деревню, Янь-у внезапно изумился и обрадовался. Он подозвал одного из чиновных людей, кто ехал с ним вместе, и сказал:

- Давным-давно, в прошлой жизни, я жил в этой деревне. Я был тогда женщиной, и у меня был муж. И я сейчас вспомнил, где был мой дом.

И велел одному из свитских всадников отправиться вглубь деревни, подъехать к указанному дому и постучать в ворота.

Открыл пожилой хозяин, и когда ему сказали, по какой причине прибыл Янь-у, он пригласил Янь-у к себе в дом. Янь-у, как только вошел в дом, посмотрел наверх, на то место на одной из стен, что было примерно в шести-семи чи над полом ${ }^{42}$, и сказал хозяину:

- Давным-давно я спрятал в тайнике высоко в этой стене «Лотосовую сутру», которую читал, когда молился, и пять моих золотых шпилек для волос. У моей сутры последняя страница седьмого свитка сгорела, так что пропали некоторые знаки. Когда я молился и читал эту сутру, то все собирался переписать сгоревшую страницу, да за хлопотами по хозяйству так и забыл.

Сразу же позвали людей, взломали стену и достали оттуда короб с сутрой. Последняя страница седьмого свитка и вправду сгорела. Когда же нашли золотые шпильки, оказалось, что все точно так, как рассказал Янь-у.

Хозяин слушал Янь-у и удивлялся, он же не понимал, в чем дело. Он попросил Янь-у объяснить, откуда тот все это знает, и Янь-у рассказал:

- Разве ты не узнаешь меня? Я была твоей женой и жила с тобой в этом доме. Я умерла родами.

Тут хозяин залился слезами и, горько плача, сказал:

${ }^{41}$ Вероятно, речь идет о представителе рода Цуй, который был влиятелен в Китае со времен Хань; при династиях Суй и Тан род считался одним из самых могущественных во всем Китае. Болин - название места в современной провинции Хубэй, где были земли рода Цуй.

${ }^{42}$ T.е. на высоте около 2 м.
- И правда, моя жена всегда, когда молилась, читала эту сутру, и шпильки эти принадлежали ей. Господин, ты действительно некогда был моей женой. Но вот еще что. Когда она умирала, обрезала волосы и спрятала их, но не сказала мне, куда. Господин, может быть, теперь ты объяснишь мне, где они?

Тогда Янь-у указал на софору ${ }^{43}$ в саду перед домом и сказал:

- Когда мне пришло время рожать, я обрезала волосы и спрятала их в дупло на этом дереве. Наверное, они до сих пор там лежат. Давайте проверим: пусть люди заберутся туда и поищут.

Сразу же велели людям забраться в дупло и поискать, как сказал Янь-у, и они достали из дупла те самые волосы. Хозяин увидел их и так горько заплакал, что и описать невозможно.

После того, как Янь-у рассказал все это хозяину, они крепко сдружились и беседовали между собой, как в те давние времена, когда были мужем и женой. Потом Янь-у щедро одарил хозяина всевозможными ценными вещами и уехал.

Вот ведь что получается: человек в следующей же жизни опять переродился в мире людей и вспомнил о своей прошлой жизни. Только благодаря заслуге от чтения «Лотосовой сутры» удалось дважды родиться среди людей, да еще и ясно помнить подробности своих поступков в прошлой жизни. Так передают этот рассказ.

\section{СПИСОК ЛИТЕРАТУРЫ}

1. Кондзяку моногатари-сю: (Собрание стародавних повестей) // Син Нихон котэн бунгаку тайкэй. Т. 33-37. Под ред. Конно Тоору, Икэгами Дзюнъити, Коминэ Кадзуаки, Мори Масато. Токио: Иванами, 1993-1999.

\section{REFERENCES}

1. 今昔物語集 [Konjaku Monogatari-shu]. 新 日本古典文学大系. Vol. 33-37. 東京: 岩波書店, 1993-1999. (in Japanese)

${ }^{43}$ Софора японская - листопадное дерево семейства бобовых, распространенное в Китае, Корее и Японии.

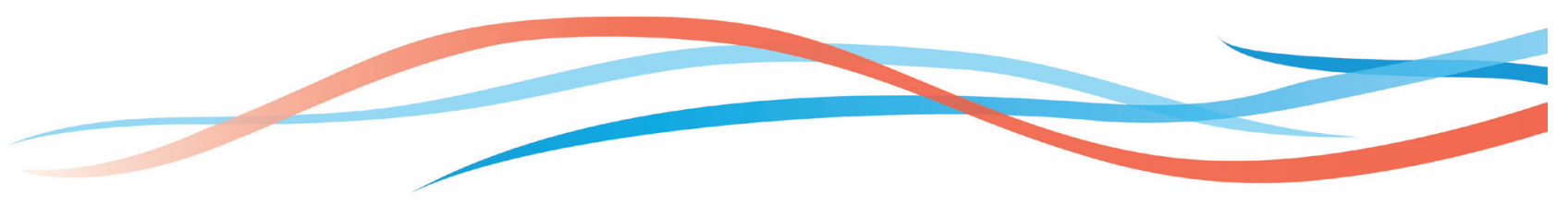

